\title{
Mycorrhization helper bacteria associated with the Douglas fir-Laccaria laccata symbiosis: effects in aseptic and in glasshouse conditions
}

\author{
R Duponnois 1,* , J Garbaye 2,** \\ 'BIOSEM, Laboratoire de Technologie des Semences, Avenue du Bois de l'Abbé, \\ F-49070 Beaucouzé; \\ 2 INRA, Centre de Recherches Forestières de Nancy, Champenoux, F-54280 Seichamps, France
}

(Received 8 October 1990; accepted 19 December 1990)

\begin{abstract}
Summary - A range of bacterial isolates from Laccaria laccata mycorrhizas and sporocarps were tested for their effect on ectomycorrhizal development of Douglas fir with L laccata. The experiments were carried out in aseptic conditions and in the glasshouse under summer and winter conditions. Fourteen isolates increased mycorrhizal development after 16 wk of growth in the summer experiment. Seven bacterial isolates displayed a significant stimulating effect in the winter experiment. All bacterial isolates tested under aseptic conditions displayed a significant stimulating effect. In the winter experiment, the treatments without $L$ laccata inoculation were contaminated by Thelephora terrestris (ectomycorrhizal basidiomycet $\epsilon$ ), a natural contaminant in the glasshouse. Six bacterial isolates displayed a significant inhibiting effect towards ectomycorrhizal infection by $T$ terrestris. Three isolates enhanced the ectomycorrhizal development of Douglas fir with $L$ laccata in all experiments. It is confirmed that the inoculation techniques in forest nurseries could be improved by such mycorrhization helper bacteria (MHB). The results with $T$ terrestris suggest that the mechanisms involved in interactions between bacteria and mycorrhizal establishment are partly fungus-specific. The results of the experiments in aseptic conditons suggest that the MHB act directly on the plant or/and on the fungus. Their stimulating effect is not the result of the suppression of root pathogens or other inhibitors of mycorrhizal infection. MHB could be used both for enhancing the infection by an introduced fungus and for reducing unwanted infection by inefficient symbionts such as $T$ terrestris. Thus, the need for soil disinfection before inoculating might be reduced.
\end{abstract}

ectomycorrhizas / bacteria / rhizosphere / Pseudotsuga menziesii / Laccaria laccata

Résumé - Les bactéries auxiliaires de la mycorhization associées à la symbiose DouglasLaccaria laccata; effets en conditions axéniques et en serre. Quarante-sept souches bactériennes isolées de mycorhizes et de carpophores du champignon ectomycorhizien Laccaria laccata ont été testées pour leur effet sur l'établissement de la symbiose entre le Douglas (Pseudotsuga menziesii) et $L$ laccata. Les expériences ont été réalisées en conditions axéniques (en tubes), ou en serre dans deux types de conditions microclimatiques : été et hiver. Quatorze isolats sur 47 ont significativement accru l'établissement des mycorhizes en serre en été (observations réalisées 16 semaines après le semis). Les taux de mycorhization allaient de 83 à $97 \%$ avec ces isolats, alors que

\footnotetext{
* Present address: INRA, Centre de Recherches Forestières de Nancy, Champenoux, F-54280 Seichamps, France

${ }^{*}$ Correspondence and reprints
} 
le taux de mycorhization dans le témoin était de 67\%. En hiver, 7 isolats bactériens sur les 14 précédents ont eu le même effet stimulant, avec des taux de mycorhization de 85 à 93\%, contre $70 \%$ dans le témoin. Ces 7 isolats, testés en conditions axéniques en tubes, ont tous présenté un effet significativement stimulant.

À 18 semaines dans l'expérience d'hiver, les traitements non inoculés par L laccata étaient contaminés par Thelephora terrestris (autre basidiomycète ectomycorhizien, contaminant naturellement présent dans la serre). Six isolats bactériens sur 14 ont significativement inhibé le développement des mycorhizes de T terrestris, qui était réduits de $29 \%$ (dans le témoin sans bactéries) à 0 à $5 \%$ avec ces isolats.

Trois isolats ont stimulé l'établissement de la symbiose entre le Douglas et $\mathrm{L}$ laccata dans toutes les expériences. Ces résultats confirment que les techniques d'inoculation ectomycorhizienne en pépinière forestière peuvent être améliorées en utilisant les bactéries auxiliaires de la mycorhization ( $M B H$ : mycorrhization helper bacteria). Les résultats concernant $T$ terrestris suggèrent que les mécanismes impliqués dans les interactions entre les bactéries et la symbiose ectomycorhizienne sont en partie specifiques à l'espèce du champignon impliqué.

Les résultats des expériences en conditions aseptiques suggèrent que les MHB agissent directement sur la plante et/ou le champignon. Leur effet stimulant ne résulte pas de la suppression de pathogènes racinaires ou d'autres organismes inhibiteurs de la formation des mycorhizes. Les MHB pourraient être utilisées à la fois pour améliorer l'établissement de la symbiose par un champignon introduit en pépinière et pour réduire les infections indésirables par des symbiontes peu efficaces comme $T$ terrestris. Le besoin de désinfection du sol avant inoculation pourrait ainsi être réduit.

ectomycorhizes / bactéries / rhizosphère / Pseudotsuga menziesii / Laccaria laccata

\section{INTRODUCTION}

The roots of most temperate forest trees form symbiotic relationships with ectomycorrhizal fungi. It has been shown with different plant-fungus partners that bacteria present in soil, rhizosphere and mycorrhizas strongly interact with the establishment of ectomycorrhizal symbiosis, with the frequent occurrence of a stimulating effect (Bowen and Theodorou, 1979; Garbaye and Bowen, 1987, 1989; De Oliveira and Garbaye, 1989). Similar results have also been obtained with vesiculararbuscu'ar endomycorrhizas (Mosse, 1962; Meyer and Linderman, 1986; Pacovski, 1989). These mycorrhization helper bacteria (MHB) could be of practical interest for improving mycorrhizal inoculation techniques in forest nurseries.

Douglas fir is presently the dominant forest tree species used for reforestation in France. Field experiments have shown that the ectomycorrhizal fungus Laccaria laccata, when inoculated in planting stocks in the nursery, stimulates the early growth of outplanted Douglas fir (Le Tacon et al, 1988). Moreover, L laccata sporocarps always contain bacteria, suggesting that this fungus might be particularly dependent on some associated bacteria for completing its life cycle.

In this paper, a range of bacterial isolates from $L$ laccata mycorrhizas and sporocarps have been tested for their effect on ectomycorrhizal development of Douglas fir with $L$ laccata. The experiments were carried out in vitro and in the glasshouse under different climatic conditions.

\section{MATERIAL AND METHODS}

\section{Plant}

The seeds of Douglas fir (Pseudotsuga menziesii (Mirb) Franco) were from Washington State, USA (from provenance zone 421 for the first 
glasshouse experiment and 412 for subsequent experiments). They were surface-sterilized in $30 \% \mathrm{H}_{2} \mathrm{O}_{2}$ for $90 \mathrm{~min}$ and washed for $4 \mathrm{~h}$ in sterile water before sowing. For the axenic experiment, pretreated seeds were plated on glucose ( $1 \mathrm{~g}^{-1}$ ) agar in order to detect contamination. Dishes were checked daily and contaminated seeds were discarded. Germinants were used when the taproot was $1-2 \mathrm{~cm}$ long.

\section{Fungus}

The ectomycorrhizal basidiomycete $L$ laccata (Scop ex Fr) Cke, isolate S-238 from USDA (Corvallis, OR), was maintained on Pachlewski agar medium (Pachlewski and Pachlewska, 1974). Mycelial inoculum was grown for 6 wk at $25^{\circ} \mathrm{C}$ in 1.6-I glass jars containing 1.3 I vermiculite-peat mixture $(2: 3-1: 3-v: v)$ moistened with liquid Pachlewski medium.

\section{Bacteria}

Bacterial strains were isolated from sporocarps and surface-sterilized mycorrhizas of $L$ laccata associated with young plants of Douglas fir in France in a glasshouse pot experiment (S), in a nursery (Morvan, M) and in 2 plantations (Bruyères, B; and Sainte-Hélène, SH). Sporocarps were brushed clean and broken open. Pieces of tissue from inside the cap were blended in sterile water using an Ultraturax blender. Mycorrhizas were washed in running tap water, surface-sterilized in $1.5 \% \mathrm{NaClO}$ for $2 \mathrm{~min}$, rinsed 20 times in sterile water and blended under the same conditions as sporocarp tissues. The effectiveness of surface sterilization was checked by plating water from the last rinse on nutrient agar. Serial dilutions of the suspensions from sporocarps and mycorrhizas were plated on $0.3 \%$ TSA medium (trypsic soy agar, Difco) and distinctive colonies were isolated and subcultured on the same medium. Isolates from mycorrhizas were called $-B x$, and those from sporocarps were called -Bcx.

Out of 110 isolates obtained, 47 were selected for their ability to grow fast on TSA medium and for their effect on the growth of $L$ laccata, using the in vitro confrontation test described by
Duponnois and Garbaye (1990): 30 stimulating, 7 neutral and 10 inhibiting isolates.

The isolates which stimulated the ectomycorrhizal development of Douglas fir in glasshouse or in aseptic conditions were later characterized. Gram staining (Gram) was performed on 4-d-oid colonies. Morphology (Mor), motility (Mot) and presence of endospores (Spor) were examined by using suspensions of 4-d-old colonies and a phase contrast microscope. In order to detect the fluorescent bacteria (Flu), the isolates were maintained on King's B medium (King et al, 1954). The choice of a type of API gallery (API System SA, BioMérieux, Montalieu-Vercieu, France) was determined with Gram staining and 2 tests performed on bacterial colonies: action of $\beta$-galactosidase (ONPG: Ref 55601, BioMérieux, France) and presence of cytochrome oxidase (Ox: Ref 55922, BioMérieux, France).

Gram-negative isolates were examined using the API 20NE test system (API 2005), which involves the following tests: nitrate reductase (Nit); tryptophanase (Trp); production of acid metabolites from glucose (Glu); arginin dihydrolase (Adh); urease (Ure); $\beta$-glucosidase (Esc); proteolysis of gelatin (Gel); $\beta$-galactosidase (Onpg); utilization as carbon sources of glucose (Glu), arabinose (Ara); mannose (Mne), mannitol (Man), $N$-acetyl-glucosamine (Nag), maltose (Mal), gluconate (GNT), caprate (Cap), adipate (Adi), malate (Mlt), citrate (Cit), phenylacetate (Pac); presence of cytochrome oxidase (Ox).

Gram-positive isolates were examined using the API $50 \mathrm{CHB}$ test system (API 5043). The tests used were the production of acid metabolites from the carbohydrates glycerol (Gly), erythrol (Ery), D-arabinose (D Ara), L-arabinose (L Ara), ribose (Rib); D-xylose (D Xyl), L-xylose (L $X y l$ ), adonitol (Ado), $\beta$-methyl-D-xyloside (Mdx), galactose (Gal), glucose (Glu), fructose (Fru), mannose (Man), rhamnose (Rha), dulcitol (Dul), inositol (ino), mannitol (Mat), sorbitol (Sor), $\alpha-$ methyl-D-mannoside (Mdm), $\alpha$-methyl-D-glucoside (Mdg), $N$-acetyl glucosamine (Nag), amygdalin (Amy), arbutin (Arb), esculin (Esc), salicin (Sal), cellobiose (Cel), maltose (Mal), lactose (Lac), melibiose (Mel), sucrose (Sac), trehalose (Tre), L-sorbose (L Sor), inulin (Inu), melezitose (Mlz), raffinose (Raf), starch (Amd), glycogen (Glg), xylitol (X|t), gentiobiose (Gen), D-turanose (D Tur), D-lyxose (D Lyx), D-tagatose (D Tag), Dfucose (D Fuc), L-fucose (L Fuc), D-arabitol (D Ar), L-arabitol (L Ar), gluconate (Gnt), 2 ketogluconate $(2 \mathrm{Kg}), 5$ keto-gluconate $(5 \mathrm{Kg})$. 


\section{Glasshouse experiments}

The 3 components of the system (bacterium, fungus and plant) were placed in $95-\mathrm{ml}$ polythene cells filled with non-disinfected vermiculite-peat mix $(1: 1-v: v)$ and fungal inoculum $(1: 10-v: v)$. Five $\mathrm{ml}$ concentrated bacterial suspension ( $>10^{8}$ cells per $\mathrm{ml}$ ) in $0.1 \mathrm{M} \mathrm{MgSO}_{4}$ $7 \mathrm{H}_{2} \mathrm{O}$ were injected into each container with a syringe. A control treatment consisted of the fungus and the buffer solution with no bacteria. Three seeds were sown per cell, and $5 \mathrm{ml}$ of concentrated bacterial suspension in $0.1 \mathrm{M}$ $\mathrm{MgSO}_{4}, 7 \mathrm{H}_{2} \mathrm{O}$ were injected into each container with a syringe. A control treatment with no bacteria consisted of the buffer solution alone. When at the cotyledon stage, plantlets were thinned to 1 per cell. Each treatment was represented by a tray containing 40 cells. After 5 wk, a nutrient solution $\left(14.8 \mathrm{mg} \mathrm{l}^{-1} \mathrm{~N}\right.$ from nitrate and $2 \mathrm{mg} \mathrm{l}^{-1} \mathrm{P}$ ), which had previously been determined as favourable to mycorrhizal development in these conditions, was applied in excess twice a week in addition to daily watering. The trays were rotated monthly on the glasshouse bench in order to compensate for the microclimatic gradients.

Two experiments were performed under different climatic conditions, the first in summer (temperature in the glasshouse ranged from $\left.15-28^{\circ} \mathrm{C}\right)$ and the second in winter $\left(10-20^{\circ} \mathrm{C}\right)$. The photoperiod (16 h) was the same in both experiments (daylight complemented with artificial light). In the summer experiment, 47 bacterial isolates were tested for their effect on mycorrhizal development. Twenty-five isolates only, which had enhanced mycorrhizal development or had no effect in this first glasshouse experiment, were then tested in winter conditions, with and without inoculation with L laccata, in order to assess the effect of the bacteria on the naturally occurring infection of the seedlings by The/ephora terrestris, which is a contaminant ectomycorrhizal fungus present in the glasshouse throughout the year as airborne basidiospores.

Ten seedings per treatment were randomly sampled in each tray 8,12 and 16 wk after sowing for the summer experiment, and 8 and 18 wk after sowing for the winter experiment. Mycorrhizal rate (number of mycorrhizal short roots/total number of short roots) was determined and transformed by arc $\sin$ (square root). The mean value of each treatment was com- pared to that of the control with Student's $t$-test at 0.05 probability level.

\section{Experiments under aseptic conditions}

Seven bacterial isolates (MB6, SHB1, MB28, $\mathrm{BBc} 1, \mathrm{BBc6}, \mathrm{MB3}, \mathrm{SBc5}$ ), chosen among those providing the highest stimulation of mycorrhizal infection in the summer glasshouse experiment were tested. The 3 components of the system (bacterium, fungus, plant) were aseptically placed in glass test tubes $(3 \times 15 \mathrm{~cm})$ filled with autoclaved $\left(120^{\circ} \mathrm{C}, 20 \mathrm{~min}\right)$ vermiculite-peat $(1: 1, v: v)$ moistened with the nutrient solution used in the glasshouse and mixed with 1:10 (v:v) fungal inoculum. One $\mathrm{ml}$ concentrated ( $>10^{8}$ cells per $\mathrm{ml}$ ) bacterial suspension in sterile $0.1 \mathrm{M} \mathrm{MgSO}_{4}, 7 \mathrm{H}_{2} \mathrm{O}$ was injected into each tube with a syringe. $A$ control treatment consisted of the buffer solution alone. The tubes were covered with aluminium foil and the rootlet of one aseptically germinated seed was introduced in a hole in the foil and sealed with autoclaved coachwork putty (Terosta 2, Teroson). The roots were thus maintained in axenic conditions, while the aerial part of the plant freely developed outside the tube. The plants were grown for $4 \mathrm{wk}$ in a climate-controlled cabinet $\left(23^{\circ} \mathrm{C}\right.$ day, $17^{\circ} \mathrm{C}$ night, $16 \mathrm{~h}$ photoperiod with $240 \mu \mathrm{E} \cdot \mathrm{m}^{-2} \cdot \mathrm{s}^{-1}$, $80 \%$ humidity). Mycorrhizal level was determined and statistically analysed as for the glasshouse experiments.

Two experiments were run successively: the first with isolates $\mathrm{SBC} 5$ and $\mathrm{BBC} 6$, the second with isolates MB3, MB6, MB28, BBc1, SHB1. Each experiment included its own control.

\section{RESULTS}

\section{Characterization of the bacterial strains}

The morphological and physiological characteristics of the bacterial strains are presented in tables 1-III. The dominant groups were bacilli for the Gram-positive and pseudomonads for the Gram-negative, 2 of them being fluorescent. Among these 14 
isolates, as well as among the whole range of the isolates tested (data not shown), there was no clear relation between the origin of the isolates and their properties, except that almost all those from sporocarps were Gram-negative, with a high proportion of pseudomonads.

\section{Summer experiment in the glasshouse}

Results for bacteria which increased mycorrhizal development on wk 16 are presented in figure 1.

On wk 8, mycorrhizal level in the control was $60 \%$. Two bacterial isolates significantly increased mycorrhizal development: MB3 (89\%) and SBc5 (88\%). Seven isolates had no effect, and 5 isolates significantly decreased mycorrhizal development: MB2 (25\%), MB8 (20\%), MB29 (21\%), SBc4 (17\%), BBc3 (21\%).

On wk 12, mycorrhizal level in the control was $64 \%$. One bacterial isolate increased mycorrhizal development: MB3 $(90 \%)$, and 1 isolate was depressive: MB29 (39\%). Twelve isolates had no significant effect.

On wk 16, mycorrhizal level in the control was $67 \%$. Fourteen isolates out of the 47 tested displayed a significant stimulating effect, the resulting mycorrhizal rate ranging from $83 \%$ for $\mathrm{BBc} 6$ to $97 \%$ for MB3.

\section{Winter experiment in the glasshouse (fig 2)}

On wk 18, mycorrhizal level in the control with Laccaria laccata was $36 \%$. Twelve bacterial isolates out of 25 significantly increased mycorrhizal development: MB2 (77\%), MB8 (83\%), MB38 (68\%), MB48 $(75 \%)$, MB50 (59\%), MB52 (86\%), MB69 (88\%), BBc1 (75\%), BBc3 (81\%), BBc6
Table I. Morphological characteristics of the bacterial strains. For legend, see text.

\begin{tabular}{llllll}
\hline $\begin{array}{l}\text { Bacterial Gram } \\
\text { isolates }\end{array}$ & & & & \\
& & & & \\
\hline MB 2 & + & Large rods & + & - & - \\
MB 3 & + & Large rods & - & - & - \\
MB 6 & + & Large rods & - & - & - \\
MB 8 & + & Elongated & - & - & - \\
MB 38 & + & rods chains & & & \\
MB 69 69 & + & Large rods & - & + & - \\
SHB 1 & + & Thin rods & - & + & - \\
MB 28 & - & Small rods & - & - & - \\
MB 29 & - & Small rods & + & - & - \\
SBc 4 & - & Small rods & - & - & - \\
SBc 5 & - & Small rods & + & - & - \\
BBc 1 & - & Short rods & + & - & - \\
BBc 3 & - & Short rods & - & - & + \\
BBc 6 & - & Short rods & - & - & + \\
& & & & & \\
\hline
\end{tabular}

(61\%), SHB1 (63\%) and SBc3 (77\%). Thirteen bacteria had no effect. None had any inhibiting effect on symbiosis development (fig 2A).

On wk 18, mycorrhizal level in the control with $L$ laccata was $70 \%$. Seven bacterial isolates displayed a significant stimulating effect: MB8 (90.2\%), MB29 (87.1\%), MB48 (93\%), SBc1 (88\%), SBc5 (85\%), BBc3 (91\%) and SHB1 (90\%). Eighteen bacteria had no effect (fig $2 B$ ).

The treatments without $L$ laccata inoculation were contaminated by $T$ terrestris (ectomycorrhizal basidiomycete), a natural contaminant in the glasshouse (air-borne basidiospores) which had not been detected at wk 8 and was never observed in treatments where $L$ laccata formed mycorrhizas. On wk 18 (fig 3), $T$ terrestris mycorrhizal rate in the control with no bacterial inoculation was $28.6 \%$. Six bacterial isolates out of the 25 tested displayed a significant inhibiting effect toward ectomycor- 
R Duponnois, J Garbaye

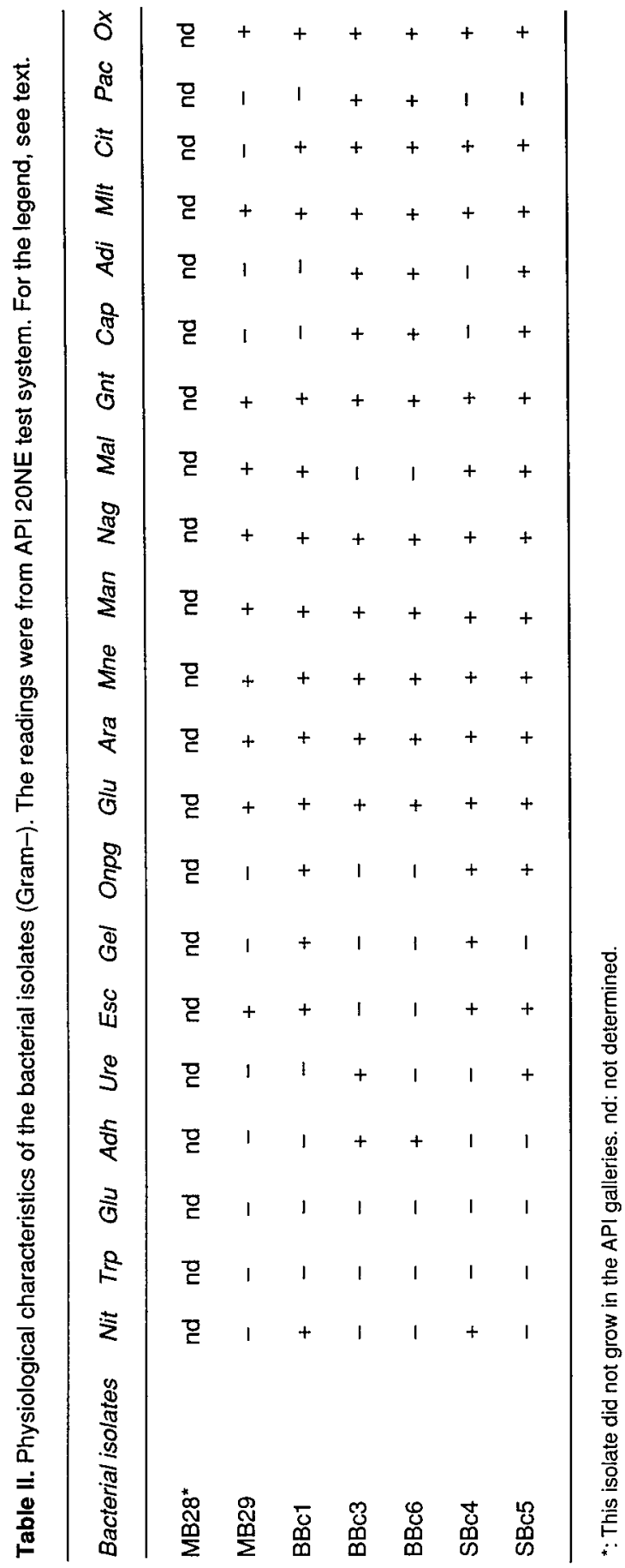


Table IIl. Physiological characteristics of the bacterial isolates (Gram + ). The readings were from API $50 \mathrm{CHB}$ test system. For legend, see text.

\begin{tabular}{|c|c|c|c|c|c|c|c|}
\hline Tests & $M B 2$ & MB 3 & $M B 6$ & $M B 8$ & $M B 38$ & $M B 69$ & $S H B 1$ \\
\hline Gly & + & + & + & + & + & + & + \\
\hline Ery & - & - & - & - & - & - & - \\
\hline D Ara & - & - & - & - & - & - & - \\
\hline L Ara & + & + & + & + & + & + & + \\
\hline Rib & + & + & - & + & + & + & + \\
\hline$D x y l$ & + & + & - & + & + & + & + \\
\hline L Xyl & - & - & - & - & - & - & - \\
\hline Adó & - & - & - & - & - & - & - \\
\hline$M d x$ & - & - & - & - & - & + & + \\
\hline Gal & + & - & + & + & - & + & + \\
\hline Glu & + & + & + & + & + & + & + \\
\hline Fru & + & + & + & + & + & + & + \\
\hline Man & + & + & + & + & + & + & + \\
\hline L Sor & - & - & - & - & - & - & - \\
\hline Rha & - & - & - & - & - & + & - \\
\hline Dul & - & - & - & - & - & - & - \\
\hline Ino & + & + & - & - & + & - & - \\
\hline Mat & + & + & + & + & + & + & + \\
\hline Sor & + & + & - & - & - & - & - \\
\hline Mdm & - & - & - & - & - & - & - \\
\hline Mdg & + & + & + & - & - & + & + \\
\hline $\mathrm{Nag}$ & - & - & - & + & - & - & + \\
\hline Amy & + & + & + & + & + & + & + \\
\hline Arb & + & + & + & + & - & + & + \\
\hline Esc & + & + & + & + & + & + & + \\
\hline Sal & + & + & + & + & + & + & + \\
\hline Cel & + & + & + & + & + & + & + \\
\hline Mal & + & + & + & + & + & + & + \\
\hline Lac & + & + & + & + & - & + & + \\
\hline Mel & + & + & + & + & + & + & + \\
\hline Sac & + & + & + & + & + & + & + \\
\hline Tre & + & + & + & + & + & + & + \\
\hline Inu & - & - & + & - & + & + & - \\
\hline Mlz & - & - & - & - & - & + & - \\
\hline Raf & + & + & + & + & + & + & + \\
\hline Amd & + & + & + & + & - & + & + \\
\hline Glg & + & + & + & + & - & + & + \\
\hline XIt & - & - & - & - & - & - & - \\
\hline Gen & + & + & + & + & + & + & + \\
\hline D Tur & + & + & - & + & - & + & + \\
\hline D Lyx & - & - & - & - & - & - & + \\
\hline D Tag & - & - & - & - & - & + & + \\
\hline D Fuc & - & - & - & - & - & - & - \\
\hline LFuc & - & - & - & - & - & - & - \\
\hline $\mathrm{D} \mathrm{Ar}$ & - & - & - & - & - & - & - \\
\hline L Ar & - & - & - & - & - & - & - \\
\hline Gnt & - & - & + & - & - & - & - \\
\hline $2 \mathrm{Kg}$ & - & - & - & - & - & - & - \\
\hline $5 \mathrm{Kg}$ & - & - & - & - & - & - & - \\
\hline
\end{tabular}




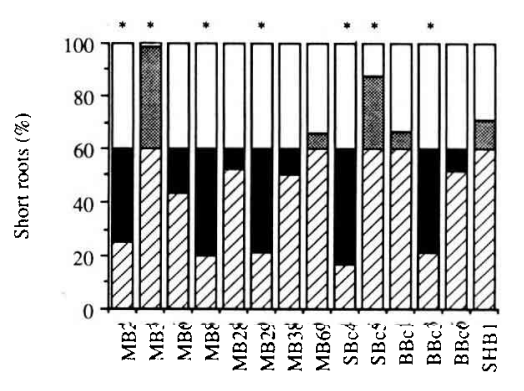

A

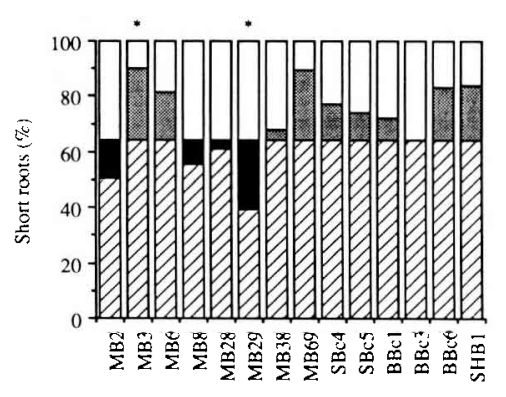

B

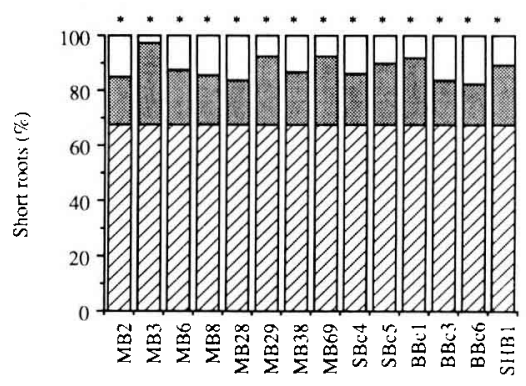

Fig 1. Summer glasshouse experiment. A: 8 wk; B: 12 wk; C: 16 wk. Empty: non mycorrhizal short roots; hatched: infection by Laccaria laccata in the control; dotted extramycorrhizal infection due to bacterial inoculation; black: reduction of mycorrhizal infection due to bacterial inoculation. *: Significantly different from the control ( $t$-test, $P=0.05)$.

rhizal infection by $T$ terrestris: MB3 (2\%), SBc1 (0\%), SBc4 (2\%), SBc5 (5\%), BBc1 $(3 \%)$ and $\mathrm{BBc} 7(0 \%)$. The remainder had no significant effect.
At the end of the 2 glasshouse experiments, 6 bacterial isolates consistently stimulated mycorrhizal infection with $L$ laccata: MB8, MB29, MB38, SBc5, BBc3 and SHB1.

\section{Experiment in aseptic conditions (fig 4)}

The 8 tested bacterial isolates significantly increased the $L$ laccata mycorrhizal level: $\mathrm{SBc} 5(80 \%)$ and BBc6 (91\%) in the first experiment, where mycorrhizal rate was $53 \%$ in the control, and MB3 $(66 \%)$, MB6 (29\%), MB28 (62\%), BBc1 (70\%), SHB1 $(66 \%)$ in the second experiment, where mycorrhizal rate was $13 \%$ in the control.

\section{DISCUSSION}

The data from all experiments summarized in table IV show that $\approx 30 \%$ of the bacteria isolated from mycorrhizas or sporocarps of $L$ laccata act as helpers and enhance the mycorrhizal development of Douglas fir seedlings by the same fungus. This suggests that many bacterial strains closely associated with the fungus have developed mutualistic interactions, although no relation was found between the efficiencies of different isolates and their taxonomic position, metabolism or origin.

The magnitude of mycorrhizal stimulation at the end of each experiment was very high: from 53 or $67 \%$ mycorrhizal rate in the control to 91 and $97 \%$ with the bacterium, respectively, with the isolate BBc6. The response of the plant-fungus symbiosis to bacterial inoculation may vary with the conditions in which the seedlings are grown, as results for some isolates varied between experiments. However, it is significant that no isolate which proved to be stimulating in an experiment displayed a negative effect in another experiment. In 

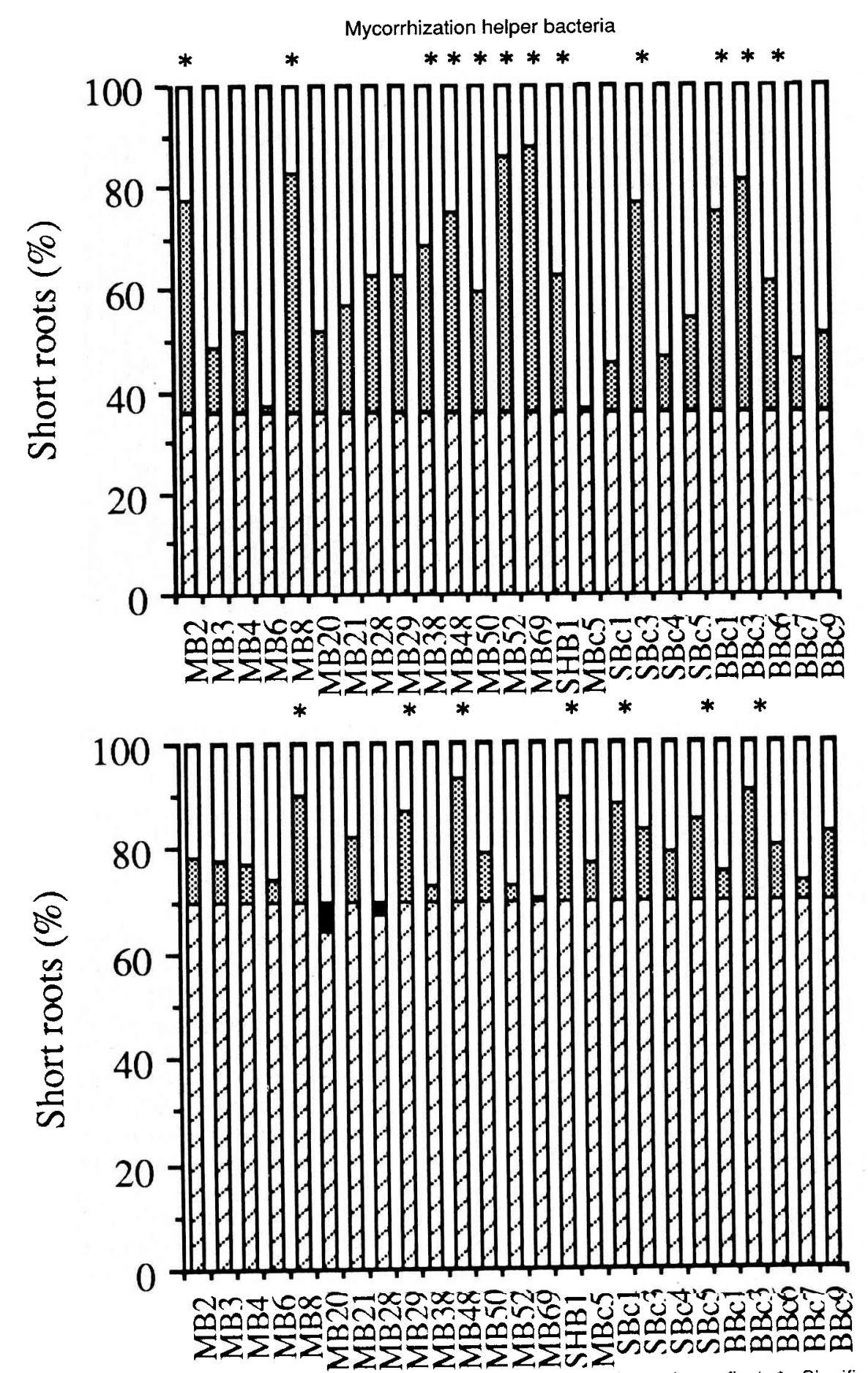

Fig 2. Winter glasshouse experiment. A: 8 wk; B: 18 wk. For the legend, see fig 1 . * : Significantly different from the control ( $t$-test; $P=0.05$ ). 


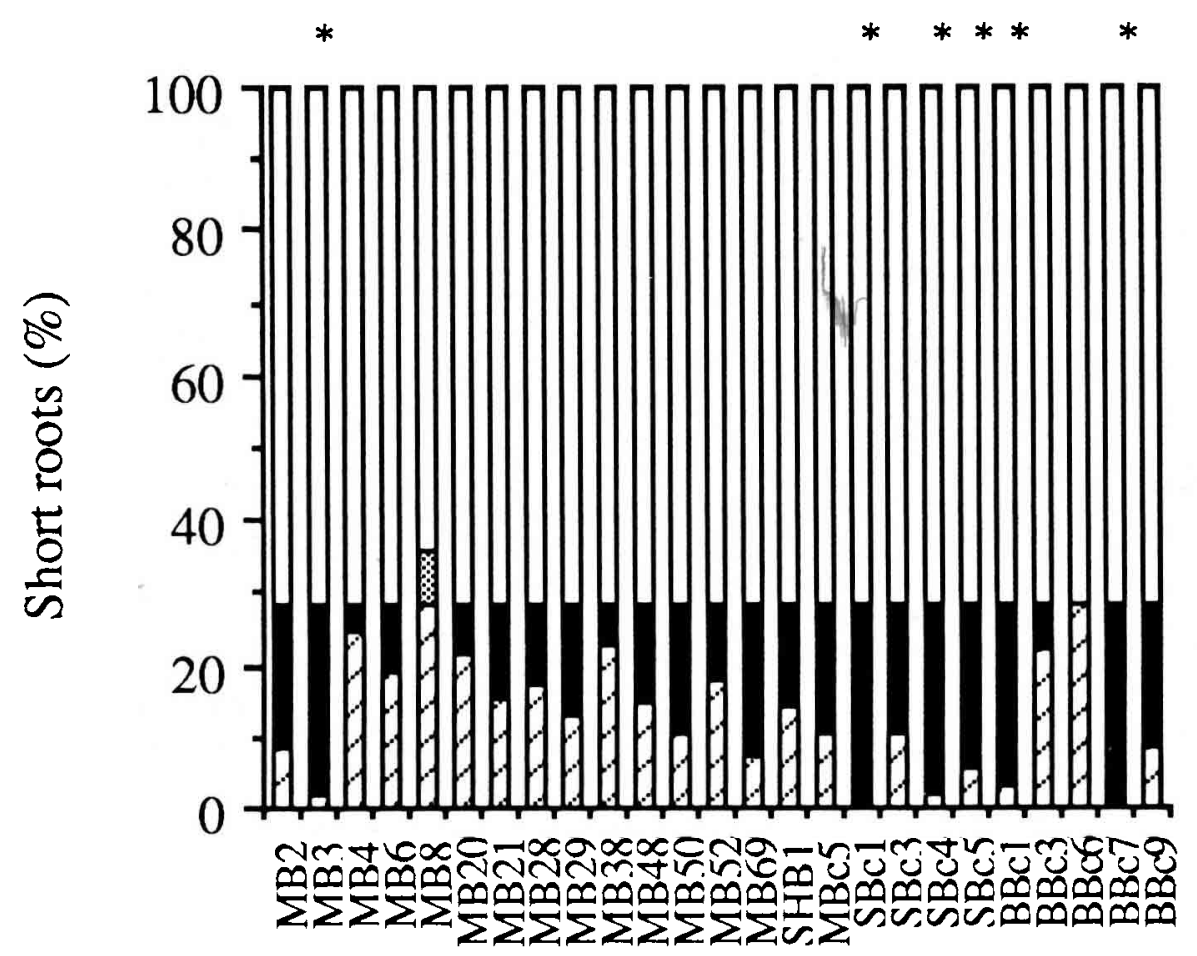

Fig 3. Effect of the bacterial isolates on mycorrhizal infection by $T$ terrestris on wk 18. For the legend, see figure 1. * : Significantly different from the control ( $t$-test, $P=0.05$ ).

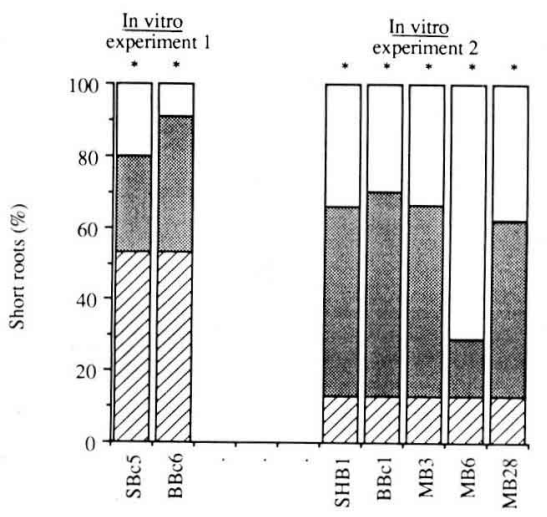

Fig 4. Experiment under aseptic conditions after $4 \mathrm{wk}$. For the legend, see figure 1. * : Significantly different from the control (t-test, $P=$ 0.05). addition, 3 isolates (SHB1, SBc5 and $\mathrm{BBc} 3$ ) proved to be efficient helpers in all experiments. Thus, the potential of such mycorrhization helper bacteria (MHB) for improving inoculation techniques in forest nurseries is confirmed, and 3 isolates at least are likely to be good candidates for practical application. Large-scale experiments in bare-root nurseries are now underway.

These conclusions are consistent with those of Garbaye and Bowen (1989) with a different model: Pinus radiata and Rhizopogon luteolus. However, these authors applied both microorganisms onto mycorrhiza-receptive roots of fully developed seedling, bypassing the important stages 
Table IV. Effect of the bacterial isolates on mycorrhizal infection of Douglas fir by Laccaria laccata (summary of results of at the end of each experiment). +: stimulation; 0 : no significant effect detected; $-:$ inhibition; no sign: not tested. ${ }^{*},{ }^{* *},{ }^{* *}$ : stimulation in 1,2 or 3 conditions, respectively.

\begin{tabular}{|c|c|c|c|c|}
\hline \multicolumn{2}{|c|}{ Bacterial isolates } & \multicolumn{2}{|r|}{ Experiments } & In vitro \\
\hline \multicolumn{5}{|c|}{ From mycorrhizas } \\
\hline * & MB1 & 0 & & \\
\hline \multirow{3}{*}{ ** } & MB2 & + & 0 & \\
\hline & $\begin{array}{l}\text { MB3 } \\
\text { MB4 }\end{array}$ & + & 0 & + \\
\hline & $\begin{array}{l}\text { MB4 } \\
\text { MB5 }\end{array}$ & $\begin{array}{l}0 \\
0\end{array}$ & 0 & \\
\hline$*$ & MB6 & + & 0 & + \\
\hline \multirow[t]{4}{*}{ ** } & MB8 & \pm & + & \\
\hline & $\begin{array}{l}\text { MB10 } \\
\text { MB20 }\end{array}$ & $\overline{0}$ & & \\
\hline & $\begin{array}{l}\text { MB20 } \\
\text { MB21 }\end{array}$ & $\begin{array}{l}0 \\
0\end{array}$ & 0 & \\
\hline & $\begin{array}{l}\text { MB21 } \\
\text { MB23 }\end{array}$ & $\begin{array}{l}0 \\
0\end{array}$ & 0 & \\
\hline ** & MB28 & + & 0 & + \\
\hline \multirow[t]{3}{*}{ ** } & MB29 & + & + & \\
\hline & MB35 & 0 & & \\
\hline & MB36 & 0 & & \\
\hline \multirow[t]{2}{*}{ * } & MB38 & + & 0 & \\
\hline & MB45 & 0 & & \\
\hline \multirow{9}{*}{ * } & MB48 & 0 & + & \\
\hline & $\begin{array}{l}\text { MB49 } \\
\text { MB50 }\end{array}$ & $\begin{array}{l}0 \\
0\end{array}$ & 0 & \\
\hline & MB51 & - & 0 & \\
\hline & MB52 & 0 & 0 & \\
\hline & MB53 & 0 & & \\
\hline & MB55 & 0 & & \\
\hline & MB61 & 0 & & \\
\hline & MB62 & 0 & & \\
\hline & MB65 & 0 & 0 & \\
\hline * & MB69 & + & 0 & \\
\hline$\star \star \star *$ & SHB1 & + & + & + \\
\hline \multicolumn{5}{|c|}{ From sporcarps } \\
\hline & MBc4 & 0 & & \\
\hline & $\mathrm{MBc5}$ & 0 & 0 & \\
\hline \multirow[t]{2}{*}{ * } & $\mathrm{SBc1}$ & 0 & + & \\
\hline & $\mathrm{SBc} 2$ & 0 & & \\
\hline \multirow[t]{2}{*}{ * } & $\mathrm{SBc} 3$ & 0 & 0 & \\
\hline & SBc4 & + & 0 & \\
\hline$* * *$ & $\begin{array}{l}\text { SBC5 } \\
\text { SBC6 }\end{array}$ & $\begin{array}{l}+ \\
0\end{array}$ & + & + \\
\hline \multirow[t]{2}{*}{ ** } & $\mathrm{BBc} 1$ & + & 0 & + \\
\hline & $\mathrm{BBc} 2$ & 0 & & \\
\hline \multirow[t]{3}{*}{$\star \star \star *$} & $\mathrm{BBc3}$ & + & + & \\
\hline & $\mathrm{BBc4}$ & 0 & & \\
\hline & $\mathrm{BBc5}$ & 0 & & \\
\hline \multirow{3}{*}{ ** } & $\mathrm{BBc6}$ & + & 0 & + \\
\hline & $\mathrm{BBc7}$ & 0 & 0 & \\
\hline & $\mathrm{BBc8}$ & 0 & & \\
\hline \multirow{2}{*}{\multicolumn{2}{|c|}{ Mycorrhizal rate of control (\%) }} & 0 & 0 & \\
\hline & & 67 & 70 & 13 and 53 \\
\hline
\end{tabular}


of survival in soil before germination of the seed and rhizosphere colonization. The present results show that a wide range of $\mathrm{MHB}$ are able to stand the time lag between sowing and primary ectomycorrhizal infections, making possible their incorporation in fungal inoculum or in seed-coating material together with mycelium or basidiospores.

The second glasshouse experiment produced unexpected results concerning ectomycorrhizal infection by $T$ terrestris, airborne spores of which contaminated the treatments with no L laccata inoculation: some bacterial isolates, which stimulated the mycorrhizal infection by $L$ laccata, reduced the infection by $T$ terrestris. In contrast, none of those tested stimulated mycorrhizal formation by $T$ terrestris. Thus, it is clear that the mechanisms involved in interactions between bacteria and mycorrhizal establishment are partly fungusspecific. From a practical standpoint, this result, together with the fact that $T$ terrestris is the main naturally-occurring poorly efficient but competitive fungus found in forest nurseries, suggest that some fungus-specific MHB might be used both for enhancing the infection by an introduced fungus and for reducing the unwanted infection by inefficient ectomycorrhizal fungi such as $T$ terrestris, reducing the need for soil disinfection before inoculation.

As far as interactive mechanisms are concerned, one which is often put forward to explain the helper effect is the suppression of root pathogens or other inhibitors of mycorrhizal establishment (Malajczuk and McComb, 1979; Nesbitt et al, 1981; Malajczuk, 1987). The present case of the in vitro experiment, where no microorganisms other than the fungus and a single bacterial isolate were present in the rhizophere, invalidates this hypothesis. Further, all the isolates tested stimulated infection in vitro in the same way as in non-aseptic glasshouse experiments where an uncontrolled microflora was present.

Three remarks concerning the experimental techniques used in this work should be considered before undertaking further research in this field: (i), it is possible to detect and interpret the stimulating potential of a bacterial isolate only when mycorrhizal rate in the control without bacteria is not already too high, and when it is at similar levels in different sets of experiments. The inoculum dose should be adjusted accordingly. Our glasshouse experiments were deficient in this respect, with mycorrhizal rates as high as $60-70 \%$ in controls. That is why the interpretation of behavioural differences of bacterial isolates in the 2 experiments is not entirely possible. The same criticism may apply to the previous work by Garbaye and Bowen (1989). (ii), We failed in the standardization of the tests in aseptic conditions, as shown by the different mycorrhizal rates in the controls of the 2 experiments. Age of fungal cultures and homogeneity of inoculation should be more acurately controlled. (iii), Aseptic mycorrhizal synthesis is an obligate technique for studying microbial interactions in the mycorrhizosphere. The systems most commonly used involve nutrient media containing organic carbon sources in the rooting medium, the aerial part of the plant being contained in the tube or the flask and thus submitted to abnormal carbon dioxide concentrations and unrealistic photosynthetic rates. As trophic interactions in the rhizosphere depend on carbon compounds released by the root, these conditions may lead to false conclusions about the nature of the interaction. That is why, in the present work, the aerial parts of the Douglas fir seedlings were left to develop out of the tubes, and the rooting substrate only contained the mineral solution needed by the plant, in order to avoid or limit the bias mentioned above. 


\section{ACKNOWLEDGMENTS}

This work was part of a research program supported by the BIOCEM Company. T Heulin (CNRS, Vandœuvre, France) and his team provided laboratory facilities and valuable advice. The authors are also grateful to JL Churin for his technical assistance and to B Dell (Murdoch University, Perth, Australia) for reviewing the manuscript.

\section{REFERENCES}

Bowen GD, Theodorou C (1979) Interactions between bacteria and ectomycorrhizal fungi. Soil Biol Biochem 11, 119-126

De Oliveira VL, Garbaye J (1989) Les microorganismes auxiliaires de l'établissement des symbioses ectomycorhiziennes (revue bibliographique). Eur J For Pathol 19, 54-64

Duponnois R, Garbaye $J(1990)$ Some mechanisms involved in growth stimulation of ectomycorrhizal fungi by bacteria. Can $\mathrm{J}$ Bot $68,2148-2152$

Garbaye J, Bowen GD (1987) Effect of different microflora on ectomycorrhizal inoculation of Pinus radiata. Can J For Res 17, 941-943

Garbaye J, Bowen GD (1989) Stimulation of ectomycorrhizal infection of Pinus radiata by some microorganisms associated with the mantle of ectomycorrhizas. New Phytol 112, 383-388

King EO, Ward MK, Raney DE (1954) Two simple media for the demonstration of pyocyanin and fluorescein. J Lab Clin Med 44, 301-307

Le Tacon F, Garbaye J, Bouchard D, Chevalier G, Olivier JM, Guimberteau J, Poitou N, Fro- chot H (1988) Field results from ectomycorrhizal inoculation in France. Proc Canadian Workshop, Mycorrhizae in Forestry (Lalonde $M$, Piché $Y$, eds) Université Laval, Québec, 51-74

Malajczuk N (1988) Interactions between Phytophtora cinnamomi zoospores and microorganisms on non-mycorrhizal and ectomycorrhizal roots of Eucalyptus marginata. Trans Br Mycol Soc 90, 375-382

Malajczuk N, McComb AJ (1979) The microflora of unsuberized roots of Eucalyptus calophylla $\mathrm{R} \mathrm{Br}$ and Eucalyptus marginata Donn ex Sm seedlings grown in soils suppressive and conducive to Phytophthora cinnamomi Rands. I. Rhizoplane bacteria, actinomycetes, and fungi. II. Mycorrhizal rots and associated microflora. Austr J Bot 27, 235-272

Meyer JR, Linderman RG (1986) Response of subterranean clover to dual inoculation with vesicular-arbuscular mycorrhizal fungi and a plant growth-promoting bacterium, Pseudomonas putida. Soil Biol Biochem 18, 185-190

Mosse $B$ (1962) The establishment of vesiculararbuscular mycorrhiza under aseptic conditions. J Gen Microbiol 27, 509-520

Nesbitt HJ, Malajczuk N, Glenn AR (1981) Bacterial colonization and lysis of Phytophthora cinnamomi. Trans Br Mycol Soc 77, 47-54

Pachlewski R, Pachlewska J (1974) Studies on Symbiotic Properties of Mycorrhizal Fungi of Pine (Pinus sylvestris $L$ ) with the Aid of the Method of Mycorrhizal Synthesis in Pure Culture on Agar. For Res Inst, Warsaw, p 228

Pacovski RS (1989) Influence of inoculation with Azospirillum brasilense and Glomus fasciculatum on sorghum nutrition. In: Nitrogen Fixation with Non-Legumes (Skimmer et al, eds) Kluwer Academic Publ, 235-239 